\title{
De NVMO Han Moll Penning 2007 - Laudatio Prof. dr. Herman J. M. van Rossum
}

Sinds ruim 10 jaar is in de statuten van de NVMO vastgelegd dat eens per vijf jaar een erepenning wordt uitgereikt aan een lid van de vereniging met bijzondere verdiensten voor het medisch onderwijs. Deze Han Moll Penning is vernoemd naar de Rotterdamse prof. dr. J. Moll (1921- 1995), betrokken bij de oprichting van de NVMO, voorzitter van de vereniging van 1976 tot 1985 , altijd zeer actief lid, langdurig redactielid van dit blad. Zijn grote verdienste voor de NVMO is na zijn overlijden, bij het 25 jarig jubileum van de NVMO, gematerialiseerd in een penning die statutair eens in de vijf jaar wordt uitgereikt. In 1997 is de penning uitgereikt aan prof. dr. Wynand H.F.W. Wijnen en in 2002 aan dr. Ko (J.A.) Smal.

De Han Moll Penning wordt toegekend op voordracht van een door het bestuur ingestelde commissie. Begin 2007 heeft het bestuur een commissie ingesteld met als leden prof. dr. Joke Denekens, prof. dr. Henk Schmidt en prof. dr. Ed van der Veen. Deze commissie heeft prof. dr. Herman van Rossum voor de penning voorgedragen. Hieronder volgt de tekst van de laudatio die tijdens het NVMO-congres is uitgesproken.

"De jury, ingesteld door het bestuur van de NVMO, had het relatief eenvoudig bij de selectie van een kandidaat voor de Han Moll Penning. Keuze genoeg uit veel excellent en jong talent. Naar de mening van de jury moet de penning echter gezien worden als een oeuvreprijs en komt de penning toe aan een iemand die over een reeks van jaren heeft bijgedragen aan de ontwikkeling van het medisch onderwijs in de lage landen. De jury heeft besloten voor de Han Moll Penning voor te dragen Herman van Rossum.

De contributie van Herman van Rossum aan het Nederlandse medisch onderwijs is groot, divers, van grote kwaliteit en originaliteit en vertoont bovendien een ongekende landelijke spreiding. Immers, in drie van de acht Faculteiten der Geneeskunde droeg hij wezenlijk bij aan de onderwijsvernieuwing.

Hoewel van geboorte Rotterdammer, werd hij tot arts opgeleid in Groningen. Na zijn artsexamen in 1972 volgde de niet alledaagse keuze voor het onderwijscoördinatorschap bij de afdeling gynaecologie en verloskunde. Herman van Rossum ontwikkelde daar een junior coschap met o.a. skillslab en video-instructies. Hij deed onderzoek van onderwijs - zeldzaam in die tijd - en promoveerde in 1977 bij Huisjes en Hofstee op een proefschrift getiteld: "Medisch onderwijs: wegen, zoeken en wegen". Belangrijk element in zijn proefschrift vormde het vergelijkend onderzoek naar vormen van probleemgestuurd onderwijs en nieuwe toetsvormen. $\mathrm{Na}$ zijn promotie werd hij in Leiden onderwijscoördinator Interne Geneeskunde en ontwikkelde er het ALCOschap, een daarna door zeven van de acht faculteiten overgenomen introductieprogramma, of Algemeen Coassistentschap, dat voorbereidt op de klinische fase van de opleiding. Het concept werd ook buiten Nederland overgenomen, bijvoorbeeld in Indonesië. Na een sabbatical aan de McMaster universiteit (1997-1989), volgde in 1990 een terugkeer naar Groningen, nu als curriculumarchitect voor het eerste curriculum dat vanuit een traditionele faculteit de principes van patiëntgestuurd leren systematisch toepaste. Onderwijs in kleine groepen, integratie van alle vakken in thematische cursussen, trimesterindeling en trimestercoördinatoren, en klinisch redeneren vormden kernelementen in het Curriculum 2000. In 1992 werd hij in Groningen benoemd tot hoogleraar Medische Onderwijskunde.

Het succes van de Groninger onderwijsvernieuwing was voor de VU aanleiding om Van Rossum naar Amsterdam te halen. In 2001 startte daar de 
ontwikkeling van het VUmc-Compas, een curriculum dat werd geënt op het Groningse, hoewel er veel opnieuw ontwikkeld en geïnternaliseerd moest worden door de VUmc-docenten en de inspanningen dus als te verwachten groot waren. Nieuwe elementen vormden o.a. het volstrekt nieuwe programma voor de wetenschappelijke vorming en de parate kennistoets. Opmerkelijk bleef het enthousiasme waarmee hij ook zijn derde faculteit bleef bestoken met steeds nieuwe plannen en inzichten. Dat daardoor de oplevering van het bouwwerk later plaatsvond dan bedoeld, was voor bestuurders een groter probleem dan voor de architect.

Herman van Rossum was binnen de drie Faculteiten Geneeskunde die hij diende actief in veel commissies en besturen. Landelijk was hij onder meer actief in de NVMO (o.a. als voorzitter) en als lid van de Werkgroep Medische Vervolgopleidingen van het Centraal College
Medisch Specialismen. Hij draagt daar opnieuw bij aan het op competenties gerichte en context gestuurde moderne medisch onderwijs in Nederland.

Internationaal was hij actief als lid van de Executive Board van zowel de Association of Medical Education in Europe als van de Association of Medical Schools in Europe.

Tientallen artikelen en boekbijdragen zijn getuige van zijn wetenschappelijke en publicistische/evangeliserende activiteiten. In waarschijnlijk honderden voordrachten is de boodschap uitgedragen dat het beter moet en kan in het medisch onderwijs.

De jury van de Han Moll Penning is dan ook van mening dat Prof. dr. H.J.M van Rossum, als erkenning en waardering voor zijn grote verdiensten voor het medisch onderwijs, de penning verleend ter gelegenheid van het NVMO Lustrum 2007, ten volle verdient." 